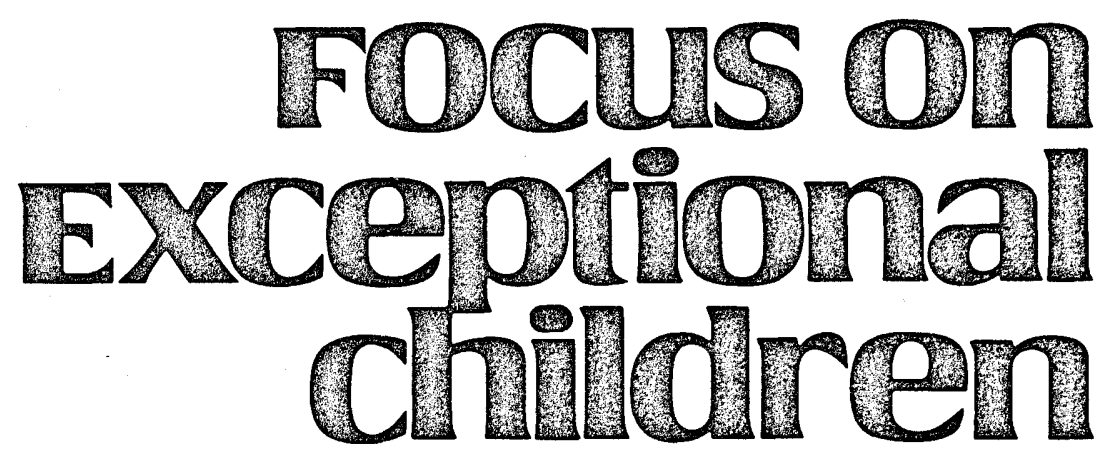

\title{
Employment As an Outcome for Mildly Handicapped Students: Current Status and Future Directions
}

\section{Eugene Edgar}

Special education serves a group of students who have a wide range of disabilities, from students with the most profound and disabling conditions to those with speech impairments only. By entrance into high school, however, some $70 \%-80 \%$ of all special education students are accounted for in the three categories of learning disabled, mildly mentally retarded, and emotionally disturbed (U.S. Department of Education, 1988). This article focuses on the employment outcomes of this group of students, referred to broadly as mildly disabled.

\section{DEFINING THE POPULATION}

Although much has been written about the characteristics of mildly disabled students, considerable debate remains about the etiology and exact nature of these conditions and, indeed, even about the ability of current technology to quantify the disabilities of students labeled learning disabled, mildly mentally retarded, and emotionally disturbed (Dunn, 1968; Gould, 1981; Hallahan \& Kaufman, 1978; Heller, Holtzman, \& Messick, 1982; Hobbs, 1975; Newkirk, Bloch, \& Shrybman, 1978; Ysseldyke, Algozzine, \& Richey, 1982). In a previous report, I referred to this group of students as the "nonquantifiably disabled" (Edgar \& Hayden, 1985). These students come to special education not by their choice but, rather, by a specific process.

This process starts with identification resulting from their low or deviant performance. Professionals, usually teachers, nominate students as potential candidates for special services because of their performance in the classroom. Formal testing for eligibility determination takes place, and students who "qualify" are admitted into special education. This "Academy Award approach" has received much abuse from the field. Yet the practice persists.

The method of entrance into special education by this population is important to consider for a number of reasons. First, this group of students is heterogeneous on many dimensions. Even within a diagnostic category, great disparity exists between individual student abilities and needs. Therefore, extreme care must be given to any analysis that attempts to lump these students together. Second, reliance on the nomination approach results in over-representation of students from the underclass. Minorities and poor people are far more likely to be referred for special education than are middle-class white students. Males, also, are over-represented in this population. Although this may be an artifact of special education procedures, the more likely cause is the unwillingness of regular education to accommodate this population (Heller, Holtzman, \& Messick, 1982). 
Given the demographic projections for the next 20 years (Hodgkinson, 1985; Wetzel, 1987), we can expect a major increase in the type of students who fall into these special education categories. Perhaps our entire system of schooling will change to accommodate this influx of culturally diverse students and thus negate the need for special education (Gartner \& Lipsky, 1987; Singer \& Butler, 1987). Then again, perhaps the special education system will be called upon to respond to the needs of these students. Regardless of the likelihood of changes in the overall educational system, special education faces a major challenge in the near future: how best to prepare these mildly handicapped students for productive lives as adults.

\section{PURPOSE OF SPECIAL EDUCATION}

Special education has been concerned primarily with one basic issue: how best to teach children with disabilities. Our intent has been to devise procedures that would result in an increased behavioral repertoire for our students. This has led us to think about "how to teach" (the technology of

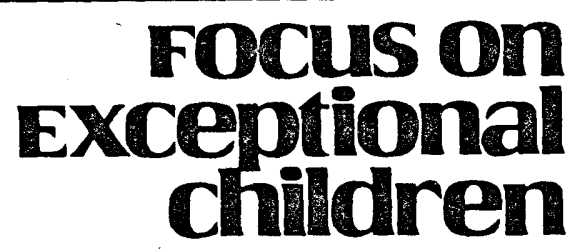

FOCUS ON EXCEPTIONAL CHILDREN (ISSN0015-511X) (USPS 203-360) is published monthly except June, July, and August as a service to teachers, special educators, curriculum specialists, administrators, and those concerned with the special education of exceptional children. This publication is annotated and indexed by the ERIC Clearinghouse on Handicapped and Gifted Children for publication in the monthly Current Index to Journals in Education (CIJE) and the quarterly index, Exceptional Child Education Resources (ECER). It is also available in microform from Xerox University Microfilm, Ann Arbor, MI. Subscription rates: Individuals, \$24 per year; institutions, $\$ 30$ per year. Copyright (C) 1988, Love Publishing Company. All rights reserved. Reproduction in whole or part without written permission is prohibited. Printed in the United States of America. Second class postage is paid at Denver, Colorado.

POSTMASTER: Send address changes to:

Love Publishing Company

Executive and Editorial Office

1777 South Bellaire Street

Denver, Colorado 80222

Telephone (303) 757-2579

EDITORIAL BOARD

Edward L. Meyen

University of Kansas

Richard J. Whelan

University of Kansas Medical Center

Stanley F. Love

Publisher
Carolyn Acheson

Senior Editor instruction), "what to teach" (the content of our curriculum), and most recently "where to teach" (the debate on integration, mainstreaming). Certainly the first two questions (how and what) have dominated our thoughts and energies and are basically the parameters of education. The "where" issue can be viewed either as a method issue (how best) or as a policy issue broader than education (recognition of human rights). Regardless of which question is addressed, however, there is an implication that "correct" answers to these questions will result in better outcomes for our students. But just exactly what are these outcomes supposed to be?

Certainly enhanced behavioral repertoires are part of the desired outcomes of special education. We desire that our graduates be competent in reading, knowledgeable about our political process, committed to our social structure, jobready for employment, able to care for their personal needs, and capable of contributing to society. We want our students to be competent. But is that all we desire? I contend that most of us truly believe we are increasing the probability that our students will have a "good quality of life." Although we focus on skill building (and knowledge and attitudes), we sincerely believe these skills will make a difference in the lives of our students.

For mildly handicapped students, the relationship between special education and regular education, especially at the secondary level, is, at best, unclear. Should special education students be mainstreamed into the regular curriculum (with added support), or should an alternative curriculum be developed? Part of the answer to this debate can be found if we can agree upon an outcome for mildly handicapped students. The Office of Special Education and Rehabilitative Services (OSERS) took a major step in this direction in publishing the "Bridges Model" (Will, 1984). This model has been generally accepted by the field of special education. We have come to view special education as "an outcomeoriented process encompassing a broad array of services and experiences that lead to employment" (Will, 1984, p. 1).

What is still unresolved is whether this goal can be accomplished in the mainstream for mildly handicapped students or whether alternative programs are needed. The least restrictive environment (LRE) mandate of PL 94-142 challenges special education to find methods of keeping students in the regular curriculum. Basic human rights philosophy, especially in light of the over-represented underclass in mildly handicapped programs, also suggests a more inclusive approach.

Additionally, there is considerable support for the notion that all students-those planning to continue their formal education beyond high school, as well as those who plan to enter the work force immediately-need the same set of experiences. Chester Finn, the current Assistant Secretary for Research and Improvement in the U.S. Department of 
Education, advocates this view. Finn has identified three missions for schools: to prepare students with skills for (a) the social system in which we live, (b) personally fulfilling lives, and (c) the next phase of their lives, whether it be higher education or employment (Finn, 1986).

A similar view, but with a rationale based on adolescent development, is provided by Wehlage (1983). In comparing specific skill training outcomes (job training) to training in more general coping skills (e.g., self-management, conflict resolution, problem solving), Wehlage advocates for the latter. With this approach, schools can be viewed as a metaphor for life (Susan Hasazi, personal communication June, 1988).

So how can schools perform these functions? First we must take a look at how successful the schools have been to date, and then speculate on what could be done in the future.

\section{CURRENT DATA BASE ON OUTCOMES IN SPECIAL EDUCATION}

The 1980s have produced a mass of follow-up and followalong studies of graduates of special education (Catterall \& Stern, 1986; Clemmons \& Dodrill, 1983; Edgar, Levine, Levine, \& Dubey, 1988; Fardig, Algozzine, Schwartz, Hensel, \& Westling, 1985; Gil \& Edgar, 1988; Hasazi, Gordon, \& Roe, 1985; Hasazi et al., 1985; Horn, O’Donnell, \& Vitulano, 1983; Levin, Zigmond, \& Birch, 1985; Linden \& Forness, 1986; Mithaug, Horiuchi, \& Fanning, 1985; Ross, Begab, Dondis, Giampiccolo, \& Meyers, 1985; Wehman et al., 1982; White, Schumaker, Warner, Alley, \& Deshler, 1980; Zigmond \& Thornton, 1985; Sitlington, 1987). Undoubtedly I have missed additional studies. The point is: Data on outcomes are not lacking. I will attempt to summarize the highlights of findings regarding these students.

Available data suggest that about $50 \%$ of all high school students do not go on to higher education (Hamilton, 1986). On the other hand, there is a growing trend toward the idea of lifelong learning, and the probability that in the future a majority of the American adult population will be engaged in formal education of some sort (Hodgkinson, 1985). Regardless, many individuals move directly from high school into the work force. The majority of mildly handicapped students attempt to make this transition. How do they do?

Unfortunately, many of the follow-up studies do not break out their results by type of disability. Overall, about $60 \%$ of mildly disabled students find employment within a year of exiting the school system. When type of disability is controlled, however, employment rates vary from $70 \%$ for learning disabled students (Zigmond \& Thornton, 1985) to $47 \%$ for mildly retarded students (Hasazi, Gordon, Roe,
Hull, Finck, \& Salembier, 1985). Students labeled as emotionally disabled obtain employment at a rate of $60 \%$ (Neel, Meadows, Levine, \& Edgar, 1988). Nonhandicapped students tend to be employed at a rate of $70 \%$ (Edgar et al., 1988 ) to $75 \%$ (Hasazi et al., 1988).

Overall, males from special education obtain employment at a higher rate than do females (Hasazi et al., 1985; Hasazi et al., 1988; Edgar, 1987; Edgar et al., 1988). Interestingly, this discrepancy is not noted with the nonhandicapped population (Hasazi et al., 1988; Edgar et al., 1988).

Graduates tend to have higher employment rates than do those who exit the schools prior to graduation (Hasazi, Gordon, \& Roe, 1985; Salembier, 1985; Zigmond \& Thornton, 1985; Edgar, 1987). Although the employment rates vary by study and by disability, a rule of thumb is that dropouts are employed at about half the rate of graduates.

The types of jobs obtained by special education graduates, as well as their nonhandicapped peers, are entry-level jobs, with low salaries, few if any benefits, and minimal opportunity for advancement. Universally, the studies have found that the family/friend network is the primary method used to obtain employment.

In summary, we can conclude that mildly handicapped students as a group have more difficulty finding employment than do their nonhandicapped peers. Students labeled mildly mentally retarded do less well than any other subgroup. Females from special education do less well than their male counterparts, which does not seem to be the case with the nonhandicapped population. All jobs tend to be low-paying, with few benefits. There is little evidence to support the idea that differential schooling results in different outcomes. But the ability of the family (or friends) to assist individuals in obtaining work is apparent. The bottom line is that graduates do much better than dropouts in finding jobs.

\section{EDUCATIONAL PARADIGM}

What does education try to do for mildly handicapped students? In my view, the overall belief is that we (in education) can "fix" these students. Our attempts to alter instructional procedures while we keep students in mainstream settings imply that we have the technology to overcome their disabilities. Is that possible?

Although education comprises a wide range of theories, the "fix-up" paradigm is rather simple. A human is a combination of genetic make-up and environmental influences. Manipulation of the genetic structure and regeneration of nerve cells remain beyond our current technology. Environment, however, is another matter. Education is based on the premise that behavioral repertoires, attitudes, feelings, 
and mental states can be manipulated through arrangement of the external environment. Careful thought is given to organizing and sequencing experiences in such a manner that human characteristics are altered in a desired direction. The gifts of Fröebel, the controlled learning environment of Guggenbühl, the sequencing of tasks by Itard, the errorless learning of Montessori, the discovery of adolescence by G. Stanley Hall, Dewey's idea of active learning, Piagetian developmental sequences, the operant learning of Skinner-all are milestones in the development of a pedagogy.

There is absolutely no doubt that current state-of-the-art educational technology will (and does) produce massive positive changes in human beings. With few exceptions, a well designed and implemented program of special education, given enough time, will produce competent behavioral repertoires in almost all human beings. With careful planning, collaborative use of resources, American ingenuity, tenacity, commitment, and time, our goals of an improved quality of life for our students can be achieved. Or so goes current thought.

Over the past few years, I have come to question this line of thinking. I have been an educator all my professional life and, until recently, had simply "accepted" these ideas. I also accepted the notion that, overall, most people in this country are doing better (in terms of quality of life) than they were, say, 10 years ago. These two ideas blend together to form a type of incrementalism - we are on the right track; we just have to keep slogging along, adding a little here and there, and eventually we will succeed. I no longer believe this.

I am not convinced that our current educational system is producing the outcomes we think it should. With the exception of students with visual disabilities only, hearing impairment only, and physical disability only, there is little evidence that special education students can be prepared to compete with their nonhandicapped peers. Special education has been effective only with students whose prosthetic environments allow them to input or output information. With few exceptions, however, students with impaired mental abilities (i.e., retardation, learning disabilities) continue to compete at a disadvantage with their nondisabled peers. The fix-up paradigm is not working very well for these students in terms of post-school success. Specifically, in terms of students finding employment, I would argue that the social status of the family has much more influence than does type of schooling.

\section{SOCIAL JUSTICE}

A number of data sets can be used to review the current political status in the United States. The pastoral letter on
Catholic social teaching and the U.S. economy is one excellent source (Economic Justice for All, 1986). According to this document, an estimated 33 million Americans live below the poverty level, with an additional 20-30 million very needy people. Between 1968 and 1978, merely $25 \%$ of our population lived under the poverty level at one time or other. Since 1973, the proportion of people living below the poverty level has increased by one third. The top $10 \%$ of our population controls $86 \%$ of our wealth. Although this group remains stable, members of the middle class are falling into the under class. We are becoming a country of relatively few who have much and many who have little.

The employment situation in this country continues to deteriorate. Eight million persons are actively looking for work ( $7 \%$ of the work force), with an additional $5 \%$ working in part-time jobs who want full-time work or who have given up looking for work. Since 1979, 2 million heavy industry jobs have been lost, which were replaced by 500,000 jobs for nurse's aides, 500,000 janitorial openings, 400,000 fast-food positions, and 100,000 office clerk slips. Half of these new jobs pay poverty-level wages (Robertson, 1988). Most of the new jobs pay no benefits and offer no career ladder opportunities.

Health-care delivery in the United States is a national disgrace. We rank 19th in the world in infant mortality and, for our Black population, the infant mortality rate places us 28th in the world (Children's Defense Fund, 1988). Our medical technology is first class; our health delivery system is third rate.

The homeless in our country are increasing at an alarming rate. In Rachel and Her Children (1988), Jonathan Kozol paints a picture of despair for thousands of homeless people. But the homeless are not confined to New York City and Chicago. Families with young children live in cars, under bridges, and on sidewalk heat vents in Minneapolis, Seattle, and Nashville. Some home-based programs for preschool handicapped children provide services to children living in cars. Head Start programs are being developed in shelters for homeless families.

These trends of increasing poverty and increase in size of the underclass have been present for the last two decades. Ever since World War II, there has been a steady increase, or a leveling, of the percentages of poor people. Things are not getting better.

If these data are accurate, I contend that our current educational theory offers little hope for solving the problem of unemployment among students with mild disabilities. No matter how hard we work our students, competent though they may well be, they will not be competitive with the top $70 \%$ of our adequately employed population. The data suggest that what will make the difference are family connections. Students with "connected" families will get jobs. 
Students without such connections will be unable to escape poverty. The cycle will be unbreakable through standard educational intervention.

\section{ALTERNATIVE SOLUTIONS}

To my way of thinking, we have a serious problem in terms of employment outcomes for special education students. As an aside, I should note that I firmly believe there is much more to the quality of life than employment. Friends, experiencing joy, feelings of self-esteem, adventure and excitement, freedom of choice, reasonable living situations - the range of events, feelings, and experience we all value-make up quality. I believe that, we, as educators, always must keep these values clearly before us. In our society, employment, and the money earned from employment, plays a critical rule in everyone's quality of lifehence the focus on employment. But we must remain aware that employment and jobs do not guarantee quality of life (Halpern, 1985; Halpern, Nave, Close, \& Nelson, 1986).

What are some possible solutions for special education to consider? I will suggest a few, in an increasing order of radical change.

\section{Beef Up Vocational Training}

Vocational education programs for students with special needs have been in place for a number of years. More recently, considerable effort has been directed toward adapting regular vocational education programs to meet the needs of students from special education (Meers, 1980). Some programs have expanded on-the-job training to include actual paid work while the students are still in school. These efforts all share a common philosophy: Certain general work skills (e.g., dependability, following directions, accepting feedback, appropriate social interaction, honesty) can be taught. In addition, people can acquire specific job or technical skills that will increase their employability.

Attempts to implement programs such as these have ranged from K-12 career education (Brolin, 1983) to relatively short-range intensive intervention. To date, results have been less than spectacular. Proponents often claim that poor results are a result of improper program implementation. And the current trend toward higher academic standards has decreased funding and interest in vocational programs in many areas.

Although I believe that programs like these should be continued and expanded, I doubt if they will have a major long-term impact on the overall issue. The students most in need of such programs often are excluded because of behavioral or general attitude problems. Unless placement and follow-along support programs are available, many of the students with appropriate skills will not locate or maintain employment after graduation. If my earlier analysis of the current social-economic situation is correct, there are simply not enough jobs available that pay "livable" wages for youth entering the job market. Still, I would like to see an increase in educational funds to vocational education, especially in terms of postsecondary options for mildly disabled students.

\section{Alter Instructional Goals}

Many recommendations have been made to alter the desired outcome of secondary education (Wehlage, 1983; Finn, 1986). Most of these focus on strengthening students' problem-solving skills and coping ability as alternatives to academic outcomes. I always have been intrigued with these recommendations but never have clearly understood how programs such as these could be implemented.

A recent publication has provided an outline of such an instructional model (Mithaug, Martin, Agran, \& Rusch, 1988). This problem-solving model is based on the idea that students fail to achieve success after school because they are not taught to set their own goals or to make decisions for themselves. Rather, according to Mithaug et al., our current instructional procedures teach students to be dependent on teachers for making all learning decisions. Thus, current instructional procedures, while focusing on basic academic or vocational skills, actually create dependent learners. This results in students' not being skilled in pursuing lifelong learning opportunities. Further, these students are poorly prepared to compete for jobs that require on-thejob learning for advancement.

Mithaug and his colleagues recommend that students should be taught the following skills: goal setting, planning, independent learning, self-evaluation, and adjustment. Their curriculum, How to Teach Success Strategies to Students with Special Needs (Mithaug, Martin, \& Husch, 1988) focuses on the instructional strategies to teach these skills, which include assessing decision making and teaching independent performance, self-evaluation, goal setting, and making adjustments. These curriculum recommendations are logical and address many of the problems with our current instructional practices. Whether the procedures are successful, however, remains to be seen. Virtually no data exist on the long-term outcomes of such instruction. As with enhanced vocational programs, the Mithaug et al. strategies appear to be worthy of considerable further study.

\section{Develop Mentor Programs}

One of the consistent findings of follow-up studies of 
high school graduates is the importance of the family/friend network in obtaining jobs and, indeed, coping with the problems of everyday life. The influence of this network may be more powerful than the type of instruction a student receives, or even his or her disability.

Adjustment to adult life is difficult for almost all people. For those with disabilities, this adjustment is even more of a problem. In the specific area of employment, Hamilton (1986) points out that American industry is not willing to give youth responsible positions. Only more mature individuals (age 22 and above) seem to have the opportunity to acquire meaningful employment. Hamilton calls this the "floundering period" in the lives of youth. For those who attend college or join the military, the floundering period is not as obvious as for those who attempt to enter the job market upon exiting from high school.

This transition period, from high school to the adult world, is the time that is most difficult for special education students. Because few attend postsecondary education, most flounder in the job market or attempts at employment. Often the students try one job and another, perhaps community college or some form of specialized vocational training, and then another job.

Andrea Zetlin and her colleagues (Zetlin \& Hosseini, 1987; Zetlin \& Murtaugh, 1987) have conducted a number of ethnographic studies of mildly handcapped students during this transition time frame. Those authors have clearly documented the floundering period and the importance of mentors. Mentors are adults to whom youth turn for advice, counsel, and perhaps financial assistance, but always friendship. For some youth, parents, older brothers or sisters, or family friends fill this role (the family/friend network). For others, however, no one fills this role. These young adults flounder without help.

For students who do not have a well developed family/ friend network, a mentor system would provide a meaningful support service. How to develop and implement such a system has yet to be proposed-much less tested. Certainly, depending on volunteers or existing social services (public or private) will not be sufficient. I believe that fruitful research could be pursued in this area.

\section{Develop an Alternative System}

As logically seductive as the above three proposals may seem, I do not believe any of them will be adequate to deal with the multiple problems facing youth with disabilities. These youth-the majority from poor families with few powerful social networks-attend a schooling system in which they fail every day. Their performance in academics is clear to them, to their teachers, and to their peers. There is no way that their self-esteem cannot be seriously damaged.
Their social interactions are impaired. Those who are placed in self-contained special education classrooms suffer from the stigma of isolation and segregation. Those who are mainstreamed suffer daily abuse from their peers. The schools make few accommodations, either for learning style or for functional content.

Day after day these students are requested to do tasks they cannot do, tasks that hold little significance for their lives, tasks that bring them failure and ridicule. And we speculate about why so many complain (are "noncompliant"), or act out, or choose not to come to this setting (drop out), or drug out, or tune out. And this applies not only to mildly handicapped special education students but to a large porportion, perhaps $30 \%$, of nonhandicapped students as well.

Some of these students (both handicapped and nonhandicapped) come from families that "make them" go to school. So they tolerate the abuse. Upon graduation, those with family connections make it. Those without family connections flounder. Students who come from families that do not make them attend school drop out. The results are the same: They flounder unless their families have connections. Why attend school?

The time is ripe for a major change in secondary education. Special education should take the lead, but this is THE opportunity for the regular education initiative at the secondary level. We (in special education) should invite those in regular education who are attempting to deal with high-risk youth to join together and form a coalition for developing a meaningful alternative secondary option for youth who are not headed directly for college. This alternative must be socially valued (not the "dumbbell" school), provide opportunities for youth to engage in activities valued by the adult society, focus on problem solving and coping skills, provide opportunities to learn, practice, and demonstrate valued vocational skills, and include ongoing mentor support systems.

Pie in the sky? Perhaps. Yet other countries have options that include major components of this proposal. Hamilton (1986) reports on apprenticeship opportunities in West Germany. Saha (1985) provides a detailed report on the Australian system in which up to $60 \%$ of youth choose an alternative to high school. For students who choose to leave school to pursue an alternative schooling (e.g., vocational, apprenticeship) that leads to employment, this choice must be considered appropriate and rational.

Could we not develop rational, appropriate alternatives such as these in the United States for mildly handicapped and other students? Might not such a system prevent dropouts, tune-outs, and drug-outs? Could we not offer students a viable method to enter our society and be productive members of the adult community that does not include attending 
our current high schools? Could we not offer a meaningful alternative to students from the underclass, be they disabled or not, to partake in our society? I think it is time to try.

\section{ENTITLEMENTS-A FINAL COMMENTARY}

Those of us who work in special education and other human services often deal with the parts of our society in which the system is not functioning well. We interact with people who face discrimination because of disability or other factors. We encounter those living in poverty. We interact with young adults and their families who have no hope; who have lost faith in improving their lot; who are adrift, frustrated, in despair, lonely; no longer looking, with joy, to the morrow. We deal with the underbelly of our society.

Many of our colleagues in other areas of work do not have personal experience with this population. Their jobs and social circles insulate them from the part of the world we see. They read reports that our society is basically well and healthy, that those who are hungry simply do not know where to go for free food, that those who are unemployed are lazy, or alcoholic, or coddled by our welfare system. They read that the answer to the drug problem is learning how to say no, that the homeless are a few mentally ill people or transients who choose that life style, that infant mortality is caused by factors other than the lack of health care, that our society is on the right track and the poor have the opportunity to "fix themselves" and partake of the fruits of our country.

We have a moral and ethical duty to inform our fellow citizens that our system has major problems, that many of our citizens live in deep despair with no way out, and that we must develop bold initiatives to make things right. We should be compelled to inform others that our society, founded on a belief system that values individual dignity and personal compassion, must respond to its own ills-not to bad-mouth our way of life but, rather, to show the world, and ourselves, that our way of life is really good.

At a minimum, we must ensure that all our citizens, disabled and nondisabled, male and female, employed and not employed, young and old, have daily food, a place to live, access to basic health care, and reasonable hope that their lives, and the lives of their children, will get better. This should be an entitlement we provide for all our citizens.

\section{REFERENCES}

Brolin, D. (1983). Life centered career eucation: A competency based approach (rev.). Reston, VA: Council for Exceptional Children.

Catterall, J., \& Stein, D. (1986). The effects of alternative school programs on high school completion and labor market outcomes. Educational Evaluation \& Policy Analysis, 8(1), 77-86.
Children's Defense Fund. (1988). Health of America's children: Maternal and child health data. Washington, DC: Author.

Clemmons, D.C., \& Dodrell, C.B. (1983). Vocational outcomes of high school students with epilepsy. Journal of Applied Rehabilitation Counseling, 14, 49-53.

Dunn, L.M. (1968). Special education for the mildly retarded: Is much of it justifiable? Exceptional Children, 35, 5-22.

Economic Justice for All. (1986). A pastoral letter on Catholic social teaching and the U.S. economy. Washington, DC: National Conference of Catholic Bishops.

Edgar, E. (1987). Secondary special education: Is much of it justifiable? Exceptional Children, 53, 555-561.

Edgar, E., \& Hayden, A.H. (1985). Who are the children special education should serve and how many children are there? Journal of Special Education, 18, 523-539.

Edgar, E., Levine, P., Levine, R., \& Dubey, M. (1988). Washington state follow-along studies 1983-1987: Final report. Seattle, WA: University of Washington, Experimental Education Unit, Child Development Mental Retardation Center.

Fardig, D.B., Algozzine, R.F., Schwartz, S.E., Hensel, J.W., \& Westling, D.L. (1985). Post secondary vocational adjustment of rural mildly handicapped students. Exceptional Children, 52, 115-121.

Finn, C.E. (1986). A fresh option for the non-college-bound. Phi Delta Kappan, 68(4), 234-238.

Gartner, A., \& Lipsky, D.K. (1987). Beyond special education? Toward a quality system for all students. Harvard Educational Review, 57, 367-396.

Gould, S.J. (1981). The mismeasure of man. New York: W.W. Norton.

Hallahan, D.P., \& Kaufman, J.M. (1978). Labels, categories, behaviors: ED, LD, and EMR reconsidered. Journal of Special Education, 11, 139-147.

Halpern, A.S. (1985). Transition: A look at the foundations. Exceptional Children, $5 l(6), 479-486$.

Halpern, A.S., Nave, G., Close, D.W., \& Nelson, D. (1986). An empirical analysis of the dimensions of community adjustment for adults with mental retardation in semi-independent living programs. Australia \& New Zealand Journal of Developmental Disabilities, 12, 147-157.

Hamilton, S.F. (1986). Excellence and the transition from school to work. Phi Delta Kappan, 68(4), 239-242.

Hasazi, S., Gordon, L., \& Roe, C. (1985). Factors associated with the employment status of handicapped youth exiting high school from 1979 to 1983. Exceptional Children, 51, 455-469.

Hasazi, S., Gordon, L., Roe, C., Hull, M., Finck, K., \& Salembier, G. (1985, December). A statewide follow-up on post high school employment and residential status of students labeled "mentally retarded." Education \& Training of the Mentally Retarded, 222-234.

Hasazi, S.B., Johnson, R.E., Gordon, C.R. \& Hall, M. (1988, April). A statewide follow-up survey of high school exiters: A comparison of former students with and without handicaps. Paper presented at AERA meeting, New Orleans.

Heller, K.A., Holtzman, W.H., \& Messick, S. (Eds.). (1982). Placing children in special education: A strategy for equality. Washington, DC: National Academy Press.

Hobbs, N. (1975). The futures of children: Categories, labels, and their consequences. Report on the Project on Classification of Exceptional Children. San Francisco: Jossey-Bass.

Hodgkinson, H.L. (1985). All one system: Demographics of educationkindergarten through graduate school. Washington, DC: Institute for Educational Leadership.

Horn, W., O'Donnell, J., \& Vitulano, A. (1983). Long-term follow-up studies of learning-disabled persons. Journal of Learning Disabilities, $16,542-555$.

Kozol, J. (1988). Rachel and her children. New York: Crown Publishers.

Levin, E., Zigmond, N., \& Birch, J. (1985). A follow-up study of 52 learning disabled students. Journal of Learning Disabilities, 13, 542547.

Linden, B.E., \& Forness, S.R. (1986, September). Post-school adjustment of mentally retarded persons with psychiatric disorders: A ten-year follow-up. Education \& Training of the Mentally Retarded. 
Meers, G.D. (1980). Handbook of special vocational needs education. Rockville, MD: Aspen Systems Corp.

Mithaug, D.E., Horiuchi, C.N., \& Fanning, P.N. (1985). A report on the Colorado statewide follow-up survey of special education students. Exceptional Children, 51(5), 397-404.

Mithaug, D.E., Martin, J.E., Agran, M., \& Rusch, F.R. (1988). Why special education graduates fail: How to teach them to succeed. Colorado Springs, CO: Ascent Publications.

Mithaug, D.E., Martin, J.E., \& Husch, J.V. (1988). How to teach success strategies to students with special needs. Colorado Springs, CO: Ascent Publications.

Neel, R.S., Meadows, N., Levine, T., \& Edgar, E.B. (1988). What happens after special education: A statewide follow-up study. $\mathrm{Be}$ havioral Disorders, 13, 209-216.

Newkirk, D., Bloch, D., \& Shrybman, J. (1978). An analysis of categorical definitions, diagnostic methods, diagnostic criteria and personnel utilization in the classification of handicapped children. Reston, VA: Council for Exceptional Children.

Robertson, J.O. (1988, February 20). A new depression is moving closer. Seattle Times, A-11.

Ross, R.T., Begab, M.J., Dondis, E.H., Giampiccolo, J.S., Jr., \& Meyers, C.E. (1985). Lives of the mentally retarded: A forty-year follow-up study. Stanford, CA: Stanford University Press.

Saha, L. J. (1985). The legitimacy of early school leaving: Occupational orientations, vocational training plans, and educational attainment among urban Australian youth. Sociology of Education, 58, 228-240.

Singer, J.D., \& Butler, J.A. (1987). The Education for All Handicapped Children Act: Schools as agents of social reform. Harvard Educational Review, 57, 125-152.

Sitlington, P.L. (1987). Iowa statewide follow-up data. Des Moines, IA: Department of Education.

Wehlage, G.G. (1983). The marginal high school student: Defining the problem and searching for policy. Children \& Youth Services Review, $5,321-342$.

Wehman, P., Hill, M., Goodall, P., Cleveland, P., Brooke, V., \& Pentecost, J.H. (1982). Job placement and follow-up of moderately and severely handicapped individuals after three years. Journal of the Association for the Severely Handicapped, 7, 5-16.

Wetzel, J.R. (1987). American youth: A statistical snapshot: Youth and America's future. Washington, DC: William T. Grant Foundation, Commission on Work, Family and Citizenship.

White, W.J., Schumaker, J.B., Warner, M.M., Alley, G.R., \& Deshler, D.D. (1980). The current status of young adults identified as learning disabled during their school career (Research report \#21). Lawrence: University of Kansas, Institute for Research in Learning Disabilities.

Will, M. (1984). Bridges from school to working life. Programs for the handicapped. Washington DC: Office of Special Education \& Rehabilitative Services, Office of Information \& Resources for the Handicapped.

Ysseldyke, J.E., Algozzine, B., \& Richey, L. (1982). Judgment under uncertainty: How many children are handicapped? Exceptional Children, 48, 531-534.

Zetlin, A.G., \& Hosseini, A. (1987). Moving toward adult status: Six case studies of mildly learning handicapped young adults who left school. Unpublished paper, School of Education, University of Southern California, Los Angeles.

Zetlin, A.G., \& Murtaugh, M. (1987). Friendship patterns of mildly learning handicapped and nonhandicapped high school students. Los Angeles: University of Southern California, School of Education.

Zigmond, N., \& Thornton, H. (1985). Follow-up of postsecondary-age learning disabled graduates and drop-outs. Learning Disabilities Research, $l(1), 50-55$.

U.S. Department of Education. (1988). Tenth annual report to Congress on the implementation of the Education of the Handicapped Act. Washington, DC: U.S. Government Printing Office.

Partial support for developing this article was provided by a grant (\#G008530049) from the Office of Special Education and Rehabilitative Services (OSERS), U.S. Department of Education. Points of view stated here do not necessarily represent official positions of OSERS. Connie Pious provided assistance in preparing this manuscript.

\section{professional update}

\section{NEW BOOK}

\section{Reading/Learning Disability: An Ecological Approach}

\section{Jill Bartoli and Morton Botel}

The authors of this new book propose an ecological model to replace the traditional diagnostic-prescriptive subskills approach to understanding reading failure. Their ecological approach views the student within the interacting classroom, school, family, and community social systems; and the language approach to reading across the curriculum encompasses the total student experience, background, and expression.

The wholistic view of the ecosystems of reader, text, and social context draws from recent social interaction and metacognitive research on the comprehension and composing processes, as well as sociolinguistic theory about learning in classrooms and communities. The book will be useful for curriculum planners, reading and learning disability spe- cialists, mainstream and special education teachers, and college students in courses on remedial reading, diagnosis and evaluation of learning disabilities, and reading methods.

Teachers College Press, Columbia University, is the publisher of this 266-page paperback.

$$
* * *
$$

The nonprofit Institute for Theatre-Learning in New York has adapted the theatre format to children with learning disabilities, and turned it into an award-winning program. Based on the "new 3 R's"-reasoning, responsibility, and respect-S.T.A.G.E.S. enhances social, communication, and academic skills based on recognizing and fostering each child's talents and potential.

For example, 10-year-old Teresa had visual memory and sequencing problems, which led to low frustration tolerance and poor self-esteem. But she had perfect pitch and could learn intricate melodies readily, which enabled her to gain recognition and success on stage.

The performance of each class of 50 students is the culmination of 10 months of work, under the overall direction of Bob Calderon, who has received the Outstanding Special Educator Award from the Council for Exceptional Children. Maxine Fields is the Theatre-Learning Coordinator. For more information, call 718/830-8737. 